\title{
OPTIMIZATION OF MUNICIPAL WASTE COLLECTION POINTS IN YOGYAKARTA CITY- INDONESIA
}

\author{
Bertha Maya Sopha dan Alditya Perkasa Sri Haryoto \\ Jurusan Teknik Mesin dan Industri Fakultas Teknik \\ Universitas Gadjah Mada \\ Email: bertha_sopha@ugm.ac.id
}

\begin{abstract}
ABSTRAK
Pemanfaatan kapasitas yang tidak merata seringkali menjadi masalah dalam sistem pengelolaan limbah di Yogyakarta. Masalah ini diperparah dengan tidak adanya alat keputusan untuk mengevaluasi sistem dan merumuskan strategi yang tepat. Oleh karena itu, penelitian ini bertujuan untuk menilai kinerja sistem pengelolaan limbah yang ada dan mengoptimalkan titik-titik pengumpulan limbah. Model matematis Mixed Integer Linear Programming dikembangkan dan diimplementasikan dalam Lingo 9. Temuan penelitian ini menunjukkan bahwa sistem pengelolaan limbah saat ini dikaitkan dengan total biaya harian sekitar Rp 10 juta dan pemanfaatan kapasitas $88 \%$. Beberapa skenario dikembangkan untuk menguji sistem yang optimal. Temuan menunjukkan bahwa limbah kota saat ini dapat ditangani dengan 35 titik pengumpulan yang melibatkan 15 depot dan 20 kontainer. Sistem yang dioptimalkan sesuai dengan Rp 6,3 juta dan pemanfaatan kapasitas $99 \%$, yang membuat biaya pengurangan sebesar 37\% dan peningkatan utilisasi kapasitas sebesar $13 \%$ dibandingkan dengan kinerja sistem yang ada. Berdasarkan analisis sensitivitas, volume limbah kota nampaknya merupakan faktor yang berpengaruh terhadap total biaya dan struktur jaringan. Batasan model juga dibahas.
\end{abstract}

Kata Kunci: Mixed Integer Linear Programming; Optimalisasi; Titik pengumpulan limbah kotamadya; Yogyakarta.

\section{ABSTRACT}

Uneven capacity utilization seems to be a constant problem in Yogyakarta waste management system. The problem is worsen by lack of a decision tool to evaluate the system and formulate appropriate strategy. This present study therefore aims at evaluating the performance of existing waste management systemandoptimizingmunicipal waste collection points. A mathematical model of MixedIntegerLinearProgramming was developed and implemented inLingo 9. Findings show that the current waste management system is associated to daily total cost of about IDR 10 million and capacity utilization of $88 \%$. Scenarios are developed to examine the optimized system. Findings suggest that current municipal waste can be handled with 35 collection points involving 15 depots and 20 containers. The optimized system is corresponding to IDR 6.3 millionand the capacity utilization of 99\%, which makes a reduced cost of $37 \%$ and an increasedcapacity utilization of $13 \%$ in comparison to the performance of the existing system. Based on sensitivity analysis,volume of municipal waste appears to be influential factor toward the total cost and network structure. Limitation of the model is also discussed.

Keywords: Municipal Waste Collection Points; Mixed Integer Linear Programming; Optimization; Yogyakarta. 


\section{INTRODUCTION}

Population growth has created problems related to urban waste particularly in a dense city such as Yogyakarta. Yogyakarta, the sixth denset city in Indonesia, has population density of 13,320 people per $\mathrm{km}^{2}$ (Badan Pusat Statistik, 2010). Current Yogyakarta waste management system is based on sectoral approach in which each sector handles different location of waste sources. The system has divided into five sectors, i.e., Gunungketur, Kotagede, Krasak, Malioboro-Kranggan, and NgasemGading. Malioboro-Kranggan sector handles the highest municipal waste of $195 \mathrm{~m}^{3}$ daily, corresponding to $28 \%$ of total daily municipal waste. Types three of waste collection points, i.e., depot, container, and permanent polling station are employed. The total existing waste collection points are 91 consisting of 13 depots, 20 containers, and 58 permanent polling stations.

Issues on urban waste such as waste disposal sites, illegal waste disposal, and undisplaced waste appear to be recurring problems encountered by Yogyakarta. The problems are also worsen by the fact that current waste management is not supported by sufficient decision tool which facilitates planning and evaluation of the waste management system. Planning of current waste management system is mainly based on previous practices, intuitions, and experiences with the aim of minimizing transportation cost. Lack of evaluation on the current system also hinders effective improvement as the system cannot be managed and the improvement areas cannot be identified without measuring its performance. It is not surprising that under-utilization of disposal points at one place while over-utilization of disposal points in other places frequently occur. Average utilization of depot and container are $70 \%$ and $86 \%$ respectively, while average utilization of permanent polling stations is generally overutilized (Yogyakarta EnvironmentalAgency, 2013). Moreover, the department also finds difficulties to decide the optimum number, type, and location of waste collection points.

The present study therefore aims at assessing the performance of existing waste man- agement system and then evaluating the optimal number and location of waste collection points. According to Yogyakarta Environmental Agency (2013), due touneven utilization of waste collection points, the government aims to reducepermanent polling stations in order to increase capacity utilization of depots and containers. Due to lack of the decision tool, the realization of the strategy becomes challenging. The present study contributes to understand the best way to increase utilization of both depots and containers through the elimination of permanent polling stations. Moreover, transportation network of depots and containers which employ direct delivery from either depots or containers to landfill should be treated differently from that of permanent polling stations which use milk-run delivery.

Most of literature on waste management is dominated by the optimization of collection route such as Agha (2006), Karadimaset al. (2007), and Bhambulkar (2011). This is also the case for the study of Yogyakarta waste management system. Most of the literature of Yogyakarta case focuses on optimizing route such as Prastawa (2012) who examined best route for collecting urban waste which minimizes travel time and Pramitaningrum (2013) who examined potential factors contributing to the long-term future urban waste. A study on the evaluation of current location of collection points is still lack, whereas some efforts have actually been conducted such as Aremu (2011) who determined location of collection points to optimize service coverage using ArcGIS Network Analyst, and Tjandra et al. (2006) who developed multi-criteria facility location model for municipal solid waste management in Greece.

\section{Method}

To meet the research objectives, standard procedure of developing optimization model which consists of system characterization, data collection, mathematical model formulation, implementation, verification-validation, and intepretation of results is followed. Based on the system characteristics which involve both binary and continuous variables and linear re- 
lationships among the variables, Mixed Integer Linear Programming(MILP) was then used to developmathematical models to determine a set of waste collection point locations which gives minimum total cost.

Current waste management system has operated regionally, and each region has employed three types of waste collection points (see Table 1 for the regions and waste collection points). Depots have capacity range of $24-48$ cubic meters. One up to two trucks are available in each depot to transport the waste to the landfill. Depots normally receive municipal waste through trash haulers which collect wastes from individual households and usually coordinated by local communities. Container is a portable trash bin with the capacity of 6 cubic meters. Waste loading and unloading is conducted automatically so that human labor is not needed as much as permanent polling stations. Waste retrival is carried out using a truck which directly transports the waste to landfill. Permanent polling stations have the capacity range of $1-4$ cubic meters. Municipal waste from permanent polling stations are collected in a truck with capacity of 8 cubic meters and are delivered to final landfill once the truck is fully loaded. The delivery method used by permanent polling stations is typically milkrun delivery.

As the model only considers only depots and containers, the developed mathematical modelsfollows waste flow of depots and cotainers as shown in Figure 1.

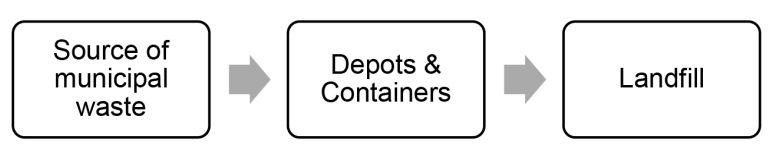

Figure 1.

Waste flow of depots and containers

Transportation of wastesources todepots/ containers normally use a collecting wagon of three-wheel vehicles which are arranged by local communities, while transportation of waste from depots/containers to the landfill use garbage trucks which are provided by the government. Figure 2 illustrate the conceptual model

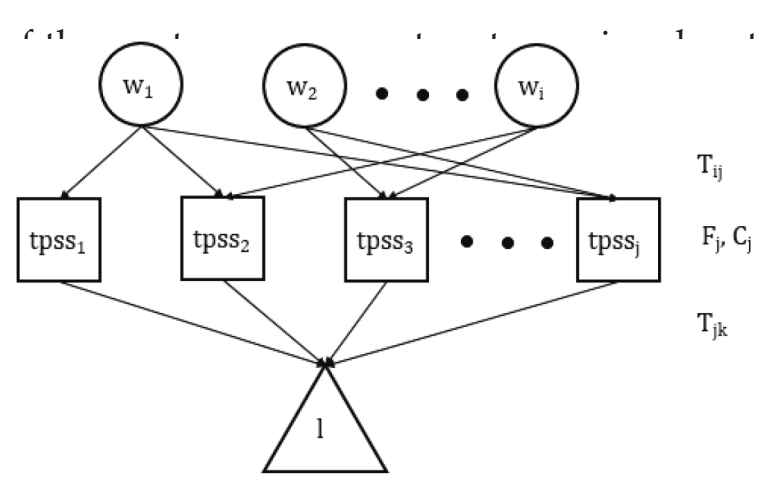

Figure 2.

Conceptual model of depot/container waste management system in Yogyakarta

Based on Figure 2, mathematical models are developed with the objective of minimizing the total cost. The total cost includes fixed cost incurred when depot/container is decided to open, and transportation cost which involves the costs of moving waste from the sources to depots/containers and then to the landfill.

Objective function:

$$
\begin{aligned}
& Z(b, x, y)= \\
& \sum_{j=1}^{J} F_{j} b_{j}+\sum_{i=1}^{I} \sum_{j=1}^{J} T_{i j} x_{i j}+\sum_{j=1}^{J} T_{j} y_{j}
\end{aligned}
$$

Constraintsof the model relates to waste mass balance as follows; the amount of waste sources is the same as that collected in depots and containers (Equation 2), the wastes received by depots and containers are never exceeded the capacity of depots and containers (Equation 3), the capacity of landfill is greater than the wastes it receives (Equation 4). Additional constraint regarding to nonnegativity is also added(Equation 5).

$$
\begin{aligned}
& \sum_{j=1}^{J} x_{j}=\sum_{i=1}^{I} w_{i} \\
& \sum_{j=1}^{j} C_{j} \geq \sum_{i=1}^{I} \sum_{j=1}^{J} x_{i j} \\
& L \geq \sum_{j=1}^{j} y_{j} \\
& x_{i j} \geq 0, y_{j} \geq 0
\end{aligned}
$$


where,

$\mathrm{w}_{\mathrm{i}}$ : quantity of waste generated at the point $\mathrm{i}\left(\mathrm{m}^{3}\right)$

$\mathrm{C}_{\mathrm{j}} \quad$ : daily capacity at waste collection point $\mathrm{j}\left(\mathrm{m}^{3}\right)$

L : daily capacity of the landfill $\left(\mathrm{m}^{3}\right)$

$\mathrm{F}_{j} \quad$ : daily-basedfixed costofdepot/container (IDR/day)

$\mathrm{T}_{\mathrm{ij}} \quad$ : transportation cost from waste sources i to depot/container $\mathrm{j}\left(\mathrm{IDR} / \mathrm{m}^{3}\right.$ )

$\mathrm{T}_{\mathrm{j}} \quad$ : transportation costfrom depot/ container $\mathrm{j}$ to the landfill (IDR $/ \mathrm{m}^{3}$ )

$\mathrm{x}_{\mathrm{ij}} \quad$ : quantity of waste that was moved from waste sources to depot/container $\mathrm{j}\left(\mathrm{m}^{3}\right)$

$y_{j} \quad:$ quantity of waste that was moved from depot/container $j$ to the landfill $\left(\mathrm{m}^{3}\right)$

$b_{j} \quad$ : binary variable 0 (if depot/container is closed) and 1 (if depot/ container is opened)

tpss $_{i}$ : waste collection points i (i.e., depots and containers)

1 : landfill

Data including waste collection points (type, capacity, and location), daily waste volume, and capacity utilization of each point, travelled distance, daily-based fixed cost, transportation cost,was collected through direct observation, interview, and secondary sources such as reports. The model was then implemented in the optimization software of Lingo 9. Verification of the model was conducted by implementing the down-scaleddeveloped model in a spreadsheet-based optimization software. The result of verification test showed that the model developed in Lingo has produced similar output of that developed in the spreadsheet-based optimization software, indicating that the implemented model was verified. With respect to validation, two types of validation, i.e., data validation and face-to-face validation, were conducted. Data was validated through triangulation, while results of the research were communicated to Yogyakarta Environmental Agencythrough face-to-face validation. The results are found to be acceptable.
To meet the research objectives, three scenarios are developed. Base scenario (Scenario 1 ) is to evaluate the performance of current waste management system by mapping current activities and associated costs. Optimization is hence not yet necessary at this stage. Second scenario is then developed following the strategy suggested by Yogyakarta Environmental Agency to reduce the number of permanent polling stations. The reasons underlying the strategy is that permanent polling stations have beentime-consuming and high cost because the permanent polling stations require many labors and time for loading and unloading the waste. Moreover, it is difficult to control and manage many small capacity of permanent polling stations. Second scenario will assess the performance of the system with completely none of permanent polling stations. Consequently, it is assumed that the municipal waste is only be handled by depots and containers. Scenario 3 is assessing optimized location of depots and containers which yield the minimum total cost while still capable of handling the municipal waste load. Sensitivity analysis is also conducted to examine the robustness of model results toward the change of input variables.

\section{RESULTS AND DISCUSSION}

\section{Scenario 1}

Base Scenario (Scenario 1) assesses current waste management system involving 13 depots, 20 containers, and 58 permanent polling stations.Table 1 presents waste management sectors with its associated waste sources to be handled, as well as its associated depots, containers, and permanent polling stations which are spatially presented in Figure 3 . The table demonstrates that, on aggregate, the total available capacity of all waste collection points is exceeding the volume of waste source by $14 \%$. This implies that current system is able to handle existing volume of municipal waste. However, the capacity utilization of individual waste collection points is different - some are under-utilized and some are over-utilized. 
Table 1

Current waste management system of Yogyakarta city

\begin{tabular}{|c|c|c|c|c|c|}
\hline Sector & $\begin{array}{l}\text { Waste } \\
\text { source }\end{array}$ & $\begin{array}{c}\text { Volume } \\
\left(\mathrm{m}^{3}\right)\end{array}$ & Depot & Container & Permanent Polling Station \\
\hline Gunungketur & $\begin{array}{l}\text { w1, w8, } \\
\text { w14 }\end{array}$ & 146 & $\begin{array}{l}\text { tpss1, } \\
\text { tpss11 }\end{array}$ & $\begin{array}{l}\text { tpss14,tpss15, } \\
\text { tpss16,tpss18 }\end{array}$ & $\begin{array}{l}\text { tpss34, tpss35, tpss36, } \\
\text { tpss37, tpss38, tpss39, tpss } 40\end{array}$ \\
\hline Kotagede & w2 & 70 & tpss2, tpss3 & $\begin{array}{l}\text { tpss17, tpss31, } \\
\text { tpss32, tpss33 }\end{array}$ & tpss41 \\
\hline Krasak & $\begin{array}{l}\text { w1, w8, } \\
\text { w14 }\end{array}$ & 140 & tpss8 & tpss29, tpss30 & $\begin{array}{l}\text { tpss42, tpss } 43, \text { tpss } 44, \text { tpss } 44, \\
\text { tpss45, tpss46, tpss47, tpss48, } \\
\text { tpss49, tpss50, tpss51, tpss52, } \\
\text { tpss53, tpss54, tpss55, tpss56, } \\
\text { tpss57, tpss58, tpss59, tpss60, } \\
\text { tpss61, tpss62, tpss63, tpss64, } \\
\text { tpss65, tpss66 }\end{array}$ \\
\hline $\begin{array}{l}\text { Malioboro- } \\
\text { Kranggan }\end{array}$ & $\begin{array}{l}\text { w1, w8, } \\
\text { w14 }\end{array}$ & 195 & $\begin{array}{l}\text { tpss5,tpss6, } \\
\text { tpss7, } \\
\text { tpss13 }\end{array}$ & $\begin{array}{l}\text { tpss19, tpss20, } \\
\text { tpss26, tpss27, } \\
\text { tpss28 }\end{array}$ & $\begin{array}{l}\text { tpss67, tpss68, tpss69, tpss70, } \\
\text { tpss71, tpss72, tpss74, tpss74, } \\
\text { tpss75, tpss76, tpss77, tpss78, } \\
\text { tpss79, tpss80, tpss81, tpss82, } \\
\text { tpss83 }\end{array}$ \\
\hline $\begin{array}{l}\text { Ngasem- } \\
\text { Gading }\end{array}$ & $\begin{array}{l}\text { w1, w8, } \\
\text { w14 }\end{array}$ & 136 & $\begin{array}{l}\text { tpss4,tpss9, } \\
\text { tpss10, } \\
\text { tpss12 }\end{array}$ & $\begin{array}{l}\text { tpss21, tpss22, } \\
\text { tpss23, tpss24, } \\
\text { tpss25 }\end{array}$ & $\begin{array}{l}\text { pss84, tpss85, tpss86, tpss87, } \\
\text { tpss88, tpss89, tpss90, tpss91 }\end{array}$ \\
\hline Capacity & & $687 \mathrm{~m}^{3}$ & $456 \mathrm{~m}^{3}$ & $162 \mathrm{~m}^{3}$ & $163,5 \mathrm{~m}^{3}$ \\
\hline
\end{tabular}

Based on aforementioned current system, the performance is evaluated and presented in Table 2. According to Table 2, the daily total cost is about IDR 10 million to handle all municipal waste to landfill. However, the utilization of waste collection points is, on average, $88 \%$. It appears that the current management system has still areas to be improved.

Table 2

Performance of existing waste management system

\begin{tabular}{l|l|l}
\hline \multicolumn{1}{c|}{ Performance Indicators } & \multicolumn{1}{c}{ Value } & \multicolumn{1}{c}{ Unit } \\
\hline Total cost & $10,114,803$ & IDR \\
Fixed cost & $7,899,685$ & IDR \\
Transportation cost from waste sources to collection points & 156,113 & IDR \\
Transportation cost from collection points to landfill & $2,059,004$ & IDR \\
\hline Undisplaced waste & 0 & $\mathrm{~m}^{3}$ \\
\hline Capacity utilization & 88 & $\%$ \\
\hline
\end{tabular}

\section{Scenario 2}

To increase the utilization of both depots and containers, Scenario 2 therefore examines if only depots and containers handle current waste, following the strategy of Yogyakarta Environmental Agency to reduce permanent polling stations. The reason underlying the strategy is that the number of permanent polling stations is too large so that it is difficult to manage particularly in route planning.
Permanent polling stations also take longer time in delivery and requires high labor cost. Moreover, permanent polling stations create unpleasant look on the city. Permanent polling stations are therefore excluded in the scenario. The mathematical model therefore only includes depots (tpss1 - tpss13) and containers (tpss14 - tpss33). Results of Scenario 2 are presented in Table 3. The total cost of Scenario 2 is $40 \%$ less than that of base scenario. Although 
the total cost is lesser, available capacity of both depots and containers is not sufficient to handle current waste which is indicated by undisplaced waste of $69 \mathrm{~m}^{3}$, corresponding to $10 \%$ of the total volume of daily generated waste. Figure 4 showing the location spread of depots and containers in Scenario 2.

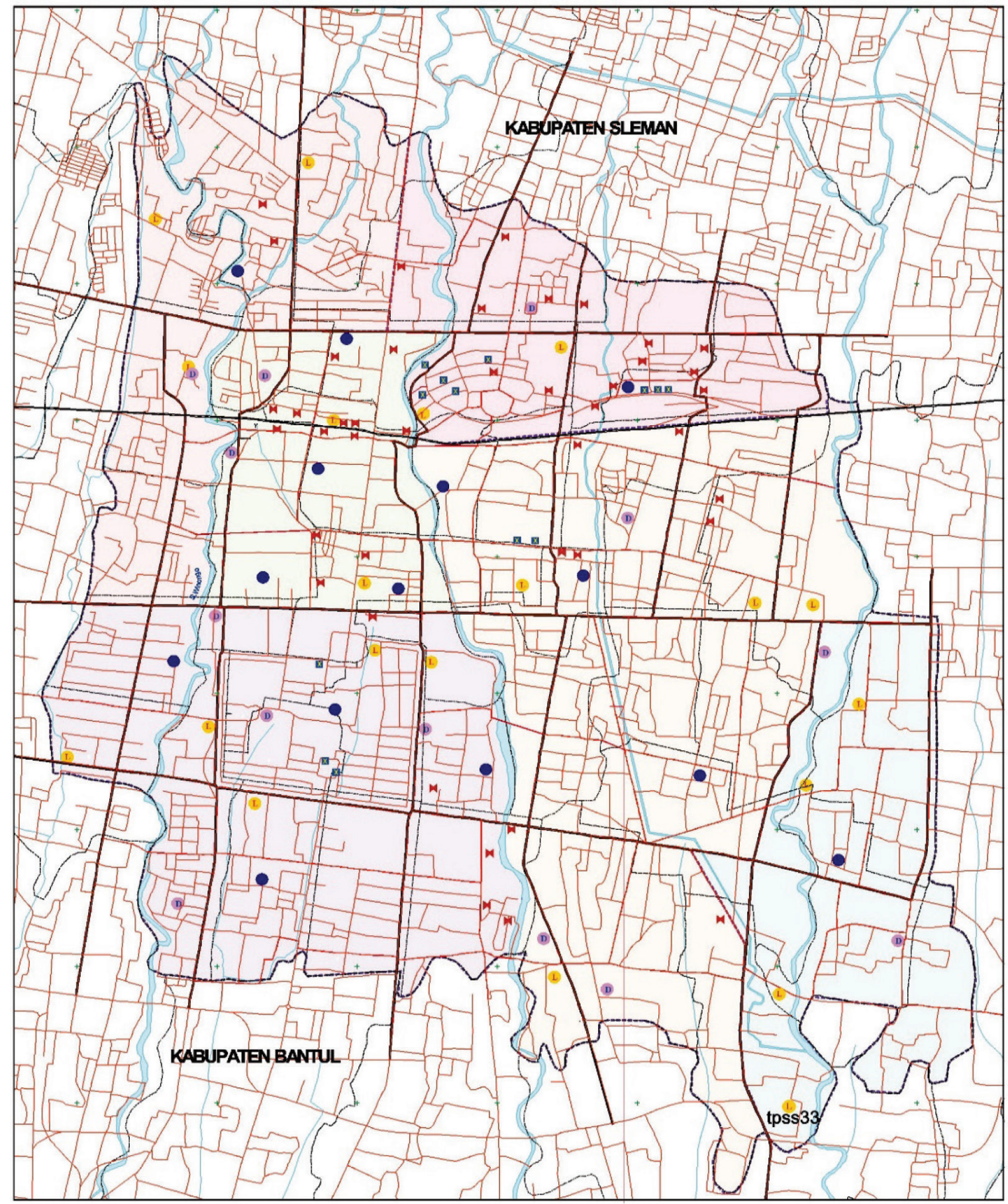

Figure 3.

Locations of depots (purple circle), containers (yellow circle), permanent polling station (red and blue squares), and aggregated waste sources (blue circle) (For interpretation of the references color in this figure legend, the reader is referred to the web version of the article) 
BERTHA MAYA SOPHA DAN ALDITYA PERKASA SRI HARYOTO OPTIMIZATION OF MUNICIPAL

WASTE COLLECTION POINTS IN YOGYAKARTA CITY- INDONESIA

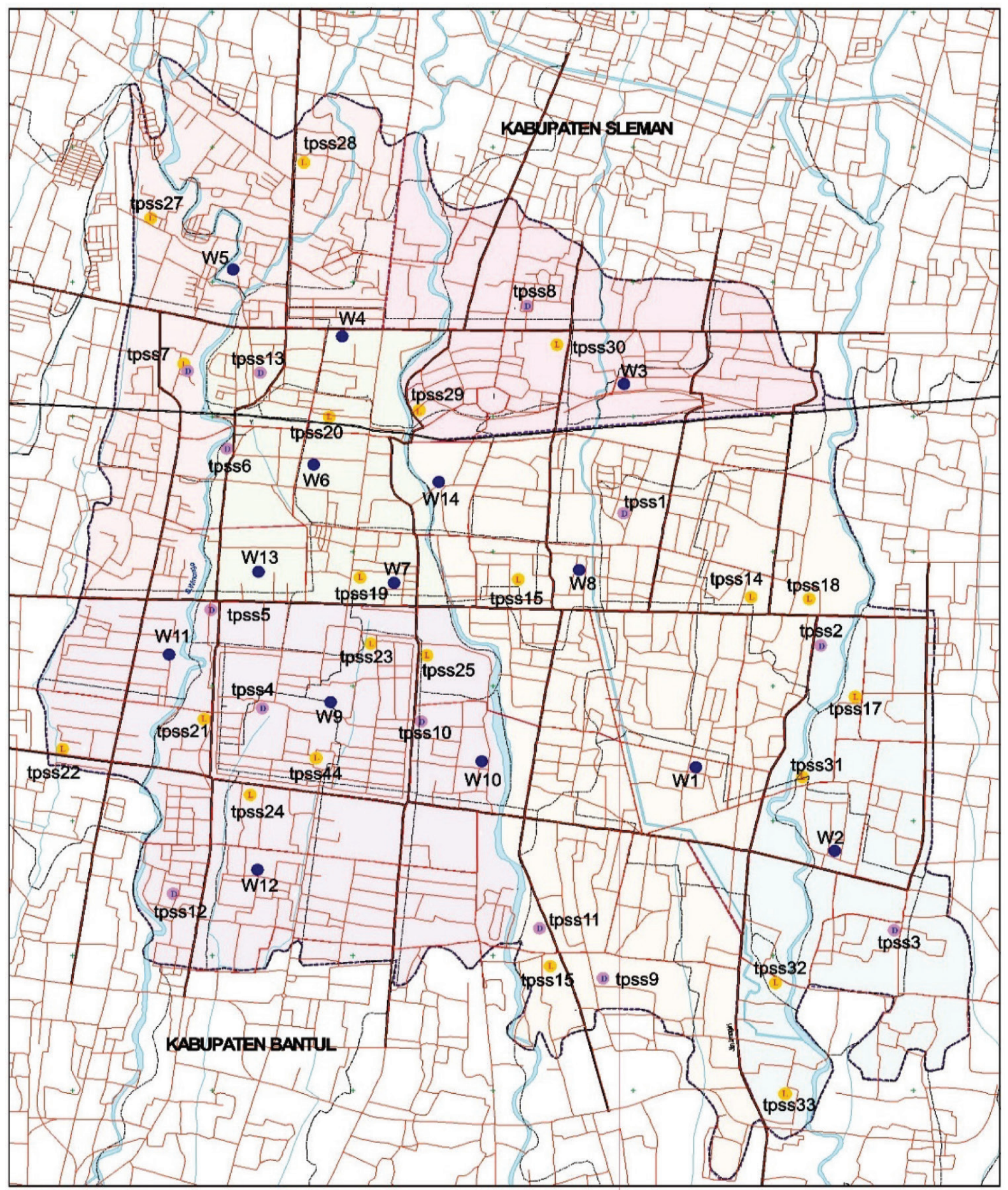

Figure 4.

Locations of depots (purple circle), containers (yellow circle) and aggregated waste sources (blue circle)(For interpretation of the references color in this figure legend, the reader is referred to the web version of the article) 
Table 3

Performance of Scenario 2

\begin{tabular}{l|l|l}
\hline \multicolumn{1}{c|}{ Performance Indicators } & \multicolumn{1}{c|}{ Value } & \multicolumn{1}{c}{ Unit } \\
\hline Total cost & $6,022,979$ & IDR \\
Fixed cost & $4,182,463$ & IDR \\
Transportation cost from waste sources to collection points & 158,047 & IDR \\
Transportation cost from collection points to landfill & $1,682,468$ & IDR \\
\hline Undisplaced waste & 69 & $\mathrm{~m}^{3}$ \\
\hline Capacity utilitization & 100 & $\%$ \\
\hline
\end{tabular}

\section{Scenario 3}

Based on the result of Scenario 2, it is necessary to have additional capacity to handle undisplaced waste. Scenario 3 therefore accomodates additional capacity to handle remaining waste. However, the question remains where the additional collection points should bebuiltso that the minimum total cost can be achieved. Adding capacity of existing depots or containers seems not to be an option due to insufficient space. Potential locations of new depots or containers areadded based on the consideration that the locationsare owned by government, were previously ever being used as depots/containers, andarehaving sufficiently available space. Based on the criteria, 11 new containers (tpss92 Hayam Wuruk, tpss93
Mangunsarkoro, tpss94 Stasiun Lempuyangan 1, tpss95 Stasiun Lempuyangan 2, tpss96 Lapangan Karang, tpss97 Argolobang, tpss98 Kusbini, tpss99 Kawasan Bagunrejo, tpss100 Kawasan Kricak, tpss101 Wongsodirjan 2, tpss 102 Alun-alun Selatan) and 2 new depots (tpss103 Pasar Kembang, tpss104 Kridosono) are proposed.The total capacity of additional depots and containers are $162 \mathrm{~m}^{3}$ which makes the total available capacity of $780 \mathrm{~m}^{3}$, exceeding the total current waste. The scenario therefore examines 15 depots and 31 containers. The scenario is simulated todetermine the best locations of both depots and containers which give the minimum total cost. Table 4 and Table 5 present the results of Scenario 3, while Figure 5 shows the spatial result.

Table 4

Open/closed depots and containers of Scenario 3

\begin{tabular}{|c|c|c|c|c|c|}
\hline Symbol & $\begin{array}{l}\text { Depots (D) and } \\
\text { Containers (C) }\end{array}$ & $\begin{array}{l}\text { Open/ } \\
\text { Closed }\end{array}$ & Symbol & $\begin{array}{l}\text { Depots (D) and } \\
\text { Containers (C) }\end{array}$ & $\begin{array}{l}\text { Open/ } \\
\text { Closed }\end{array}$ \\
\hline tpss 1 & D. Mandala Krida & $\sqrt{ }$ & tpss 24 & C. Pugeran & $\sqrt{ }$ \\
\hline tpss 2 & D. Veteran & $\sqrt{ }$ & tpss 25 & C. Jogja Tronik & $\sqrt{ }$ \\
\hline tpss 3 & D. Kotagede & $\sqrt{ }$ & tpss 26 & C. Utoroloyo & $x$ \\
\hline tpss 4 & D. Ngasem & $\sqrt{ }$ & tpss 27 & C. Bener & $x$ \\
\hline tpss 5 & D. Terminal Ngabean & $\sqrt{ }$ & tpss 28 & C. Kuboto Magelang & $x$ \\
\hline tpss 6 & D. Pringgokusuman & $\sqrt{ }$ & tpss 29 & C. RRI Telomoyo & $x$ \\
\hline tpss 7 & D. MakamUtoroloyo & $\sqrt{ }$ & tpss 30 & C. RS Bethesda & $x$ \\
\hline tpss 8 & D. Sagan & $\sqrt{ }$ & tpss 31 & C. Depokan Kotagede & $\sqrt{ }$ \\
\hline tpss 9 & D. Nitikan & $\sqrt{ }$ & tpss 32 & C. Pamukti & $\sqrt{ }$ \\
\hline tpss 10 & D. Purawisata & $\sqrt{ }$ & tpss 33 & C. Terminal Giwangan & $\sqrt{ }$ \\
\hline tpss 11 & D. Sorosutan & $\sqrt{ }$ & tpss 92 & C. Hayam Wuruk & $\mathrm{x}$ \\
\hline tpss 12 & D. DukuhBantul & $\sqrt{ }$ & tpss 93 & C. Mangunsarkoro & $\sqrt{ }$ \\
\hline tpss 13 & D. Jati & $\sqrt{ }$ & tpss 94 & C. StasiunLempuyangan 1 & $\sqrt{ }$ \\
\hline tpss 14 & C. Komplek Balaikota & $x$ & tpss 95 & C. Stasiun Lempuyangan 2 & $\sqrt{ }$ \\
\hline tpss 15 & C. Puro Pakualaman & $\sqrt{ }$ & tpss 96 & C. Lapangan Karang & $\sqrt{ }$ \\
\hline
\end{tabular}




\begin{tabular}{|c|c|c|c|c|c|}
\hline Symbol & $\begin{array}{l}\text { Depots (D) and } \\
\text { Containers (C) }\end{array}$ & \begin{tabular}{|l|} 
Open/ \\
Closed
\end{tabular} & Symbol & $\begin{array}{l}\text { Depots (D) and } \\
\text { Containers (C) }\end{array}$ & $\begin{array}{l}\text { Open/ } \\
\text { Closed }\end{array}$ \\
\hline tpss 16 & C. RS Wirosaban & $\sqrt{ }$ & tpss 97 & C. Argolobang & $\sqrt{ }$ \\
\hline tpss 17 & C. Kebun Raya Gembiraloka & $\sqrt{ }$ & tpss 98 & C. Kusbini & $\sqrt{ }$ \\
\hline tpss 18 & C. SGM & $\sqrt{ }$ & tpss 99 & C. Kawasan Bangunrejo & $x$ \\
\hline tpss 19 & C. Pasar Sore & $\sqrt{ }$ & tpss 100 & C. Kawasan Kricak & $x$ \\
\hline tpss 20 & C. StasiunTugu & $\sqrt{ }$ & tpss 101 & C. Wongsodirjan 2 & $x$ \\
\hline tpss 21 & C. Perempatan Tamansari & $\sqrt{ }$ & tpss 102 & C. Alun-Alun Selatan & $\sqrt{ }$ \\
\hline tpss 22 & C. Bugisan & $x$ & tpss 103 & D. Pasar Kembang & $\sqrt{ }$ \\
\hline tpss 23 & C. Alun-alun Utara & $\sqrt{ }$ & tpss 104 & D. Kridosono & $\sqrt{ }$ \\
\hline
\end{tabular}

Note: Open $(\sqrt{ })$, Closed $(x)$

Based on the results of Scenario 3, the optimized system is achieved through the operation of 15 depots and 20 containers in which 7 of previous containers, i.e., Komplek Balaikota, Bugisan, Kuboto Magelang, Utoroloyo, Bener, RRI Telomoyo, and RS Bethesda should be closed and 6 new containers should be opened in Mangunsarkoro, Stasiun Lempuyangan 1, Stasiun Lepmpuyangan 2, Lapangan Karang, Argolobang, Alun-alun Selatan. The proposed optimized system offers the reduction of total cost by $37 \%$ and the increased utilization of $13 \%$ in comparison to existing system.

Table 5

Performance of Scenario 3

\begin{tabular}{l|l|l}
\hline \multicolumn{1}{c|}{ Performance Indicators } & \multicolumn{1}{c}{ Value } & \multicolumn{1}{c}{ Unit } \\
\hline Total cost & $6,341,679$ & IDR \\
Fixed cost & $4,371,704$ & IDR \\
Transportation cost from waste sources to collection points & 170,836 & IDR \\
Transportation cost from collection points to landfill & $1,799,139$ & IDR \\
\hline Undisplaced waste & 0 & $\mathrm{~m}^{3}$ \\
\hline Capacity utilitization & 99.6 & $\%$ \\
\hline
\end{tabular}

\section{Sensitivity analysis}

Sensitivity analysis is conducted to examine the robustness of the model results due to the changes of input. Three variables such as fuel cost, waste volume, and fixed cost are selected for sensitivity analysis. Table 6 shows the results of sensitivity analysis which demonstrates that waste volume is the most sen- sitive variable toward the total cost of waste management system. It implies that, among the examined parameters, waste volume gives the greatest influence. The waste volume increase by $5 \%$ results in the increase total cost of $8.6 \%$. Surprisingly, fuel cost appears to be the least sensitive parameter.

Table 6

Sensitivity analysis on the total cost

\begin{tabular}{l|l|l|l|l|l|l}
\hline \multirow{2}{*}{ No. } & \multirow{2}{*}{ Parameter } & \multicolumn{5}{c}{ Changes of total cost with the changes of parameter } \\
\cline { 3 - 7 } & & $\mathbf{9 0} \%$ & $\mathbf{9 5} \%$ & $\mathbf{1 0 0} \%$ & $\mathbf{1 0 5 \%}$ & $\mathbf{1 1 0} \%$ \\
\hline 1 & Fuel cost & $-3,11 \%$ & $-1,55 \%$ & 0 & $1,55 \%$ & $3,11 \%$ \\
\hline 2 & Waste volume & $-15,79 \%$ & $-8,49 \%$ & 0 & $8,61 \%$ & $16,32 \%$ \\
\hline 3 & Fixed cost & $-6,89 \%$ & $-3,45 \%$ & 0 & $3,45 \%$ & $6,89 \%$ \\
\hline
\end{tabular}




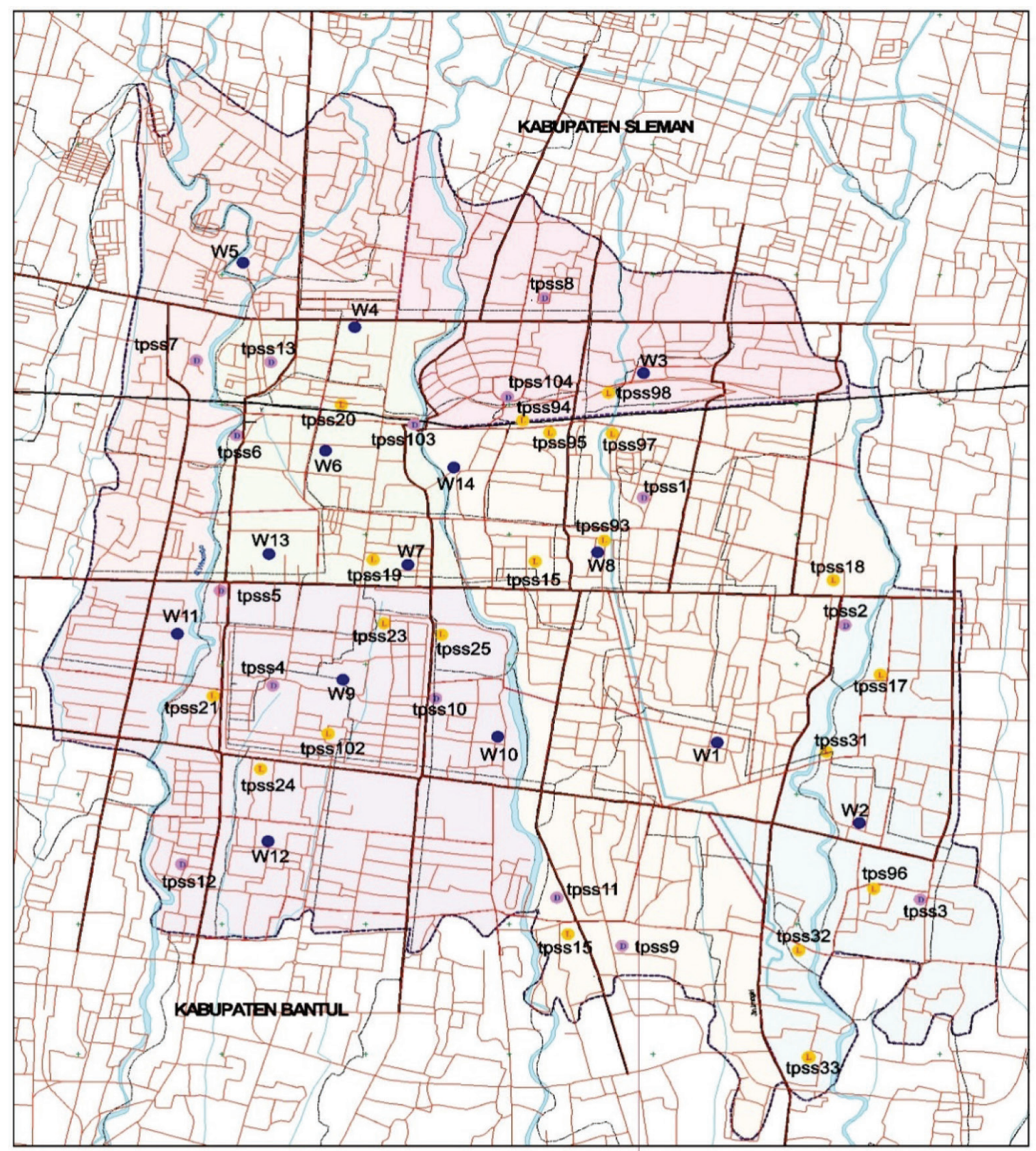

Figure 5

Locations of depots (purple circle), containers (yellow circle) and aggregated waste sources (blue circle)(For interpretation of the references color in this figure legend, the reader is referred to the web version of the article)

With respect to network structure, Table 7 indicates that only waste volume appears to be influential, where both fuel cost and fixed cost are found to be insensitive. In general, the total cost as well as the network structure may be changing by the change of waste volume. It im- plies that the system should be reviewed and examined regularly in order to keep efficient operation, or on the other way, effort to design optimal waste management system should be able to project accurately the future waste volume. 
Table 7

Sensitivity analysis on the network structure

\begin{tabular}{l|l|l|l|l|l|l}
\hline \multirow{2}{*}{ No. } & \multirow{2}{*}{ Parameter } & \multicolumn{5}{c}{ Changes of network structure with the changes of parameter } \\
\cline { 3 - 7 } & & $\mathbf{9 0} \%$ & $\mathbf{9 5 \%}$ & $\mathbf{1 0 0 \%}$ & $\mathbf{1 0 5 \%}$ & \multicolumn{1}{|c}{$\mathbf{1 1 0 \%}$} \\
\hline 1 & Fuel cost & - & - & - & - & - \\
\hline 2 & Waste volume & $-25,71 \%$ & $-11,42 \%$ & 0 & $8,57 \%$ & $20 \%$ \\
\hline 3 & Fixed cost & - & - & - & - & - \\
\hline
\end{tabular}

Although the result of the study seems promising, it is worth to discuss limitation of the model. As the model neglects permanent polling stations, the result of the study should be intepreted with care. Excluding permanent polling stations may result in that the distance between waste sources to waste collection points is too far. Future study should therefore addresses this issue. Furthermore, potential study should also work on optimizing the system including depots, containers, and permanent polling stations once the permanent polling stations are not avoidable.

\section{CONCLUSION}

Uneven capacity utilization of waste collection points indicate that current waste management system needs to be evaluated and redesigned. However, the evaluation and redesigned efforts have been unobstracted by lack of decision tool. The present research contributes to evaluate current waste management system and proposed an optimized system. Results indicate that current waste management system is corresponding to the total cost of about 10 million and capacity utilization of 88\%. Using Mixed Integer Linear Programming, the results proposed that the optimum system with no permanent polling system can be achieved through the operation of 15 depots and 20 containers. Of 15 depots, 2 new depots are added. Of 15 containers, 7 of previous containers are closed, whereas 6 new containers are opened. The optimized system corresponds to $37 \%$ reduced total cost and $13 \%$ of increased capacity utilization in compariso to those of existing system. Waste volume apperas to be influential factor on the total cost and the network structure of the system.

\section{BIBLIOGRAPHY}

Agha, S. R., 2006, Optimizing Routing of Municipal Solid Waste Collection Vehicles in Deir El-Balah - Gaza Strip, The Islamic University Journal, 14(2), 75-89.

Aremu, A., S., 2011, Optimization and Assessment of Waste Bin Locations Using Geographic Information System, available online: http://www. unilorin.edu.ng/publications / asaremu/13_AremuConf_2011.pdf, accessed on June 2013.

BadanPusatStatistik, 2010, Laporan Eksekutif Hasil Sensus Penduduk 2010 Provinsi Daerah Istimewa Yogyakarta, Badan Pusat Statistik Kota Yogyakarta, Yogyakarta.

Bhambulkar, A. V., 2011, Municipal Solid Waste Collection Routes Optimized With ArcGis Network Analyst, International Journal of Advanced Engineering Sciences and Technologies, 11(1), 202-207.

Karadimas, N.,Kolokathi, M., and Loumos, V, 2007, Municipal Waste Collection of Large Items Optimized with ArcGis Network Analyst, Proceedings 21 ${ }^{\text {st }}$ European Conference on Modelling and Simulation, 4-6 June 2007, Prague, Czech Republic.

Pramitaningrum, E., 2013, Pengembangan Model untuk Memonitor Sampah di Kota Yogyakarta dengan Pendekatan Bayesian Network, Undergraduate thesis, Fakultas Teknik Universitas Gadjah Mada, Yogyakarta. 
Prastawa, D. M., 2012, Optimasi Rute Pengambilan Sampah Berbasis Vehicle Routing Problem, Undergraduate thesis,Fakultas Teknik Universitas Gadjah Mada, Yogyakarta.

Tjandra, S. A., Erkut, E., Karagiannidis, A., dan Perkoulidis, G., 2006, A Multicriteria Facility Location Model for
Municipal Solid Waste Management in North Greece, European Journal of Operation Research, 187(3), 1402-1421.

Yogyakarta Environmental Agency, 2013, Jumlah sampah dan biaya tetap harian. 